\section{THE EFFECTIVENESS OF VARIOUS TEACHING APPROACHES ON THE PERFORMANCE OF THE VOLLEYBALL GAME}

\section{EFIKASNOST RAZNIH NASTAVNIH PRISTUPA NA UČINAK U ODBOJKAŠKOJ UTAKMICI}

\section{SUMMARY}

The aim of the study was to determine and verify the effectiveness of various teaching approaches on changes in the level of volleyball performance in the process of teaching volleyball to pupils in primary schools. In the experimental group was used the tactical approach and in the control group the techniques (traditional) approach in teaching of volleyball. The experimental group consisted of 26 pupils and the control group consisted same number of pupils. Both groups, representing 13 to 14 year old schoolgirls in primary school. Efficiency of the teaching approaches was evaluated based of game performance. Game performance was evaluated by the method of game performance assessment based on GPAI (Game Performance Assessment Instrument) through video record. To perform statistical evaluation Mann-Whitney U-test was used. When we evaluate the tactical component of game performance "position", we found out that the difference between groups is not statistically significant $(p>0.05)$. By comparison "decision-making" it was discovered that the difference, between achieved performances in groups it is statistically significant $(p<0.05)$ in favour of the experimental group. By comparison skills execution we found out, that the difference between both groups in "serving" is not statistically significant $(p>0.05)$. But by comparison of passing, setting, offensive hit and team's game performance" we found out statistically significant $(p<0.05)$ the difference between both groups in favour of the experimental group. The acquired data pointed to the fact that in generally the tactical teaching approach appears to be a more efficient method for acquiring game skills and tactical components of the game.

Key words: volleyball, teaching approaches, performance

\section{Jaroslav Popelka ${ }^{1}$ and Ratko Pavlović ${ }^{2}$}

${ }^{1}$ Department of Physical

Education and Sport, Faculty of Humanities, UMB in Banská

Bystrica, Slovakia

${ }^{2}$ Faculty Physical Education and Sport, University of East

Sarajevo, Bosnia and Herzegovina

Original scientific paper doi:10.5550/sgia.171301.en.PP UDC: 796.325 .01

Received: 12.04.2017. Accepted: 23.06.2017.

Correspondence author:

Jaroslav Popelka, PhD.

Katedra telesnej výchovy a športu Tajovského 40

97404 Banská Bystrica Slovensko

Tel: 0484467554

Jaroslav.Popelka@umb.sk

Sportlogia 2017, 13 (1), 29-37.

E-ISSN 1986-6119

COBISS.RS-ID 6768664 


\section{INTRODUCTION}

Nowadays the quality of the learning process is one of the main reasons why children in primary and high schools are not interested in physical activities. Another reason being inadequately prepared teachers who are not able to motivate pupils towards physical activities by means of didactic styles and teaching approaches. The thematic unit of sports games (traditional, non-traditional) are amongst the most popular sports activities of physical and sports education in school with the largest number of hours in the annual schedule.

According to several authors (Zapletalová, Přidal, Laurenčík, 2007; Popelka, 2013), the problem of the didactic process with every sports game and thus also with respect to volleyball is that this process teaches the pupils to play as quickly and effectively as possible, which means to reach a continual game manifestation and to awake in students a lasting interest in the game. This can be achieved by means of optimal teaching approaches amongst which are teaching methods, organisational forms, teaching processes, teacher interaction (Popelka, 2012a). Several authors (Thorpe, Bunker, \& Almond 1986; Psotta, \& Velenský, 2001; Dobrý, 2003) found that the past and present didactics and practices have been using various teaching approaches in teaching of sports games. Both in the past and present in our system of teaching of sports games used the so called technical teaching approach, which is mainly focused on practicing individual's game activities and game combinations and only after their partial managing can pupils play the game itself. This model is criticized by several authors (Zat'ková, 2003; Lukavská, 2006) who, when evaluating the teaching process in sports games, point to the fact that pupils have strong limitations in game competence. English speaking countries mainly use tactical approach in teaching sports games, which is based on pupils being encouraged to understand all aspects of the game with a concurrent increase of physical performance, motivation and enjoyment in physical education (Popelka, 2012b). This model is known as Teaching Games for Understanding, created by Bunker and Thorpe.

Authors Alison and Thorpe (1997) and Blomqvist, Luhtanen, \& Laakso (2001) claim that by using the tactical approach in teaching sports games, the pupils acquired tactical knowledge, game skills and understood all aspects of the game, whereas the pupils educated by traditional technical approach improved only their game skills. According to Popelka (2013), the main argument for using this model when teaching is to increase the motivation of pupils to participate in compulsory physical and sports education. Another research authors (Turner, \& Martinek, 1992; Rink, 1996) compared both approaches in teaching of sports games, did not discover any significant differences of the previously mentioned teaching approaches. Their research works coincide with the fact that pupils who participated in the tactical teaching approach expressed more joy and showed the same improvement in technique as well as in the game itself. When comparing the specific knowledge, neither Olosová nor Zapletalová (2014) confirmed stronger effectiveness of tactical teaching model in comparison with the technical model. Several authors dealt with the comparison of both models (̌̌ezničková, \& Zapletalová, 2014; Popelka, \& Pavlović, 2015; Žuffová, \& Zapletalová, 2015) and our article is also aimed at empirical verification and comparison of the educational effects of technical and tactical teaching approaches on volleyball performance of pupils in primary schools.

The aim of this research was to compare the effectiveness of various teaching approaches on volleyball performance of pupils in primary schools.

\section{METHODS}

In our research, we used a pedagogical experiment with two groups, representing 13 to 14 year old schoolgirls in primary school. The research took place in January 2016 until March 2016. The experimental group consisted of 26 pupils and the control group consisted same number of pupils. The research was conducted on 17 classes, of which both groups are trained 15 classes in volleyball. The first and last classes were designed to evaluate game performance.

Popelka, J.\&Pavlović, R.:The effectiveness of various...Sportlogia 2017, 13 (1), 29-37. Page 30. 
During 8 weeks of the intervention experimental group was taught by the tactical teaching approach and control group by the technical teaching approach twice a week for 45 minutes in volleyball classes.

Teaching with tactical approach: The main part of the class started with a modified game. After the modified game, there was a discussion where the teacher asked the student questions. The pupils tried to find answers to the questions. Then the teacher chose other modified games. Pupils played the most frequently modified games 2 vs. 2, 3 vs. 3, 4 vs. 4, 5 vs. 5, 6 vs. 6 games and least did technical exercises.

Teaching with technical approach: Every main part of the class began with the practice of the technique. Prior to training, the teacher explained the technique of skill, tactical use in the game and then followed by a match. The technical approach to teaching was dominated by practice techniques, 6 vs. 6 games and the least modified 3 vs. 3 .

Comparison of the use of the specifics tactical and technical approaches are reported in Table 1.

Table 1 Comparison of the use of the specifics of teaching approaches

\begin{tabular}{|c|c|c|c|c|c|c|c|c|c|}
\hline \multirow{3}{*}{$\begin{array}{l}\text { Teaching } \\
\text { approach }\end{array}$} & \multirow{3}{*}{ Group } & \multicolumn{8}{|c|}{ The specifics of teaching } \\
\hline & & \multirow{2}{*}{$\begin{array}{c}\text { Techniques } \\
\text { exercises }\end{array}$} & \multirow{2}{*}{$\begin{array}{l}\text { Modified } \\
\text { games }\end{array}$} & \multirow{2}{*}{$\begin{array}{l}\text { Official } \\
\text { game }\end{array}$} & \multicolumn{5}{|c|}{ Didactic styles } \\
\hline & & & & & 1 & 2 & 3 & 4 & 5 \\
\hline $\begin{array}{c}\text { Tactical } \\
\text { approach }\end{array}$ & $\begin{array}{c}\text { Experimental } \\
\text { group }\end{array}$ & $6,70 \%$ & $73,3 \%$ & $20 \%$ & $11,8 \%$ & $0 \%$ & $35,3 \%$ & $71 \%$ & $64,7 \%$ \\
\hline $\begin{array}{l}\text { Technical } \\
\text { approach }\end{array}$ & Control group & $46,7 \%$ & $13,3 \%$ & $40 \%$ & $58,8 \%$ & $24 \%$ & $0 \%$ & $0 \%$ & $41,2 \%$ \\
\hline
\end{tabular}

Notes: 1 - didactic style command, 2 - didactic style practical, 3 - didactic style with offer, 4 - didactic style with controlled discovery, 5 - didactic style with individual discovery

Note: The percentage of use of didactic styles represents the real number of use of teaching specifics in the classes (we used several didactic styles in one class)

In this article, we present the information containing output level of the game performance in volleyball of the pupils in experimental and control group. We used the method of observation for planned and deliberate observation of the quantity and quality course of tactical and technical game components to obtain the data. Game performance components were analyzed using audiovisual equipment. The selection of evaluated game components and criteria of their evaluation were based on the evaluation of game performance according to Mitchell, Oslin, \& Griffin (2006). Game performance evaluation took place at the last class, where each pupil played 20 minutes. The ability of decision-making, position and skill execution was evaluated.

Game components and criteria:

- Decision-making: The pupil uses the correct skill at the correct time.

Scoring Key: Appropriate: The pupil uses the correct skill at the correct time (forearm pass on $1^{\text {st }}$ touch; overhead volley on $2^{\text {nd }}$ touch; hitting action on $3^{\text {rd }}$ touch). Inappropriate: The pupil do not uses the correct skill at the correct time (hitting action on $2^{\text {rd }}$ touch)

- Position: After hitting the ball, the pupil will take the appropriate position in the court.Scoring Key: Appropriate - after hitting the ball, the pupil will take appropriate position in order to have optimal coverage of the course. Inappropriate - after hitting the ball, the pupil does not will take appropriate position in order to have optimal coverage of the course.

- Skill Execution: The student passes the ball accurately (ball reaches the intended target) Scoring Key:

Popelka, J.\&Pavlović, R.:The effectiveness of various...Sportlogia 2017, 13 (1), 29-37. Page 31. 


\section{Setting, passing}

Effective - The pupil hit the ball in accordance with the rules, technically correct, and sett, pass the ball to the teammate. Inefficient - The s pupil does not hit the ball in accordance with the rules, technically wrong, and does not sett or pass the ball towards to the teammate.

\section{Offensive hit}

Effective - The pupil hit the ball in accordance with the rules and technically correct.Inefficient - The pupil does not hit the ball in accordance with the rules and technically correct.

\section{Serving}

Effective - The pupil serve the ball in accordance with the rules and technically correct. Inefficient - The pupil does not serve the ball in accordance with the rules and technically correct.

For the evaluation of results, we used Mann-Whitney U test for independent selections and descriptive statistics. Significance was determined on standardly used $5 \%$ level $(\mathrm{p}<0.05)$.

\section{RESULTS}

The comparison of game performance of the team in experimental and control group is presented in Table 2 .

Table 2 The comparison of output evaluation of control and experimental group's game performance

\begin{tabular}{|c|c|c|c|c|c|c|c|}
\hline $\begin{array}{c}\text { Comparison } \\
\text { of the } \\
\text { groups }\end{array}$ & D & P & Se & Pa & Set & Oh & TGP \\
\hline Eg & $73.30 \%$ & $74 \%$ & $67.50 \%$ & $70.20 \%$ & $68.30 \%$ & $70.10 \%$ & $71.40 \%$ \\
\hline Cg & $62.10 \%$ & $65.20 \%$ & $60.30 \%$ & $53 \%$ & $50 \%$ & $52.80 \%$ & $57.20 \%$ \\
\hline M-W & 0.010 & 0.132 & 0.147 & 0.025 & 0.014 & 0.017 & 0.001 \\
\hline
\end{tabular}

Explanatory notes: Eg - experimental group, $\mathrm{Cg}-$ control group, $\mathrm{M}-\mathrm{W}-$ Mann Whitney $\mathrm{U}$ test $\mathrm{p}<0.05, \mathrm{D}-\mathrm{decision}$ about "what?" to do, P - position after the hitting, Se - serving, Pa - passing, Set - setting, Oh - offensive hit, TGP - team's game performance

By comparing decision-making it was discovered that the difference, between achieved performances in groups is $11.2 \%$ in favour of the experimental group, it is statistically significant $(p<0.05)$. Therefore, we can claim that the experimental group was significantly better in the evaluation of this tactical game component about "what" will the pupil demonstrate. Considering the aforementioned facts, we state that pupils in the experimental group demonstrated better ability to make a right decision in various game situations. We assume that the pupils acquired this ability due to the amount of modified games in which they also had to fulfil tactical tasks.

By comparing the performances in the position, we discovered $8.8 \%$ difference between the groups in favour of the experimental group. Despite the fact that the tactical teaching approach was used by the experimental group, in this case the difference between groups is not statistically significant $(p>0.05)$. We assumed that the pupils in the experimental group would achieve statistically significant differences in comparison with the control group, whereas the pupils in the experimental group had more opportunities for solving the aspect of this tactical game due to the fact they played modified games. In such games the teacher asked a question such as: "What part of the court should you stand/take position after hitting the ball?" which in this case lead to choosing the right position on court after hitting the ball. 
The difference in serving between the groups was $7.2 \%$ in favour of the experimental one. Such a difference is not statistically significant $(p>0.05)$. We assume that the experimental stimulus did not significantly influence the learning and improvement of serving, because pupils served on shorter distance more often. Despite the fact that serving did not show statistically significant differences, we think that the ability to cope with the stress during the game is an important requirement for success. We assumed that the experimental group, which played a variety of modified games, can better cope with the stress and pupils would ultimately play better as individuals.

By comparison the passing between the groups was a difference of $17.2 \%$ in favour of the experimental group, which is statistically significant $(p<0.05)$. Based on the achieved performances in passing, we assume that experimental stimulus influenced this defensive game activity in a more positive manner. We want to highlight the level of mastering this game activity of the individual is very low in the control group. If the players can not properly pass to one another, on such level of performance it is difficult for a setter to pass the ball for a spike.

By comparison the setting between the groups a difference of $18.3 \%$ in favour of the experimental group, which is statistically significant $(\mathrm{p}<0.05)$. We assume that the game performance of settings in the control group was significantly influenced by the previous game activity - passing. We suppose that if the passing was better, the control group would achieve better performances in setting and attacking.

By comparison the offensive hit between the groups a difference of $17.3 \%$ in favour of the experimental group, which is statistically significant $(\mathrm{p}<0.05)$. We assume that the amount of matches with fewer players enabled the pupils in the experimental group to be more frequently in contact with the ball in the offensive phase and subsequently to achieve successful offensive hits.

By evaluating the team's game performance a difference of $14.2 \%$ in favour of the experimental group. This difference is statistically significant $(\mathrm{p}<0.05)$. The Volleyball game is characterised by an individual's previous game activity of the individual influences over the next one. This was also confirmed by our research. Whereas the passes and sets in the experimental group had a success rate of approximately $70 \%$ and so the offensive hit with a $70.10 \%$ rate of success. All the game activities of the individual in the control group were just above $50 \%$ and therefore the success rate of the offensive hit was also only $52.8 \%$. From the achieved results we can state that from an statistical significance point of view the experimental group was better only in one tactical game component "decision-making". We were surprised that in the second tactical component "position" the experimental group did not achieve better results in comparison with the control group. On the other hand, by the evaluation of this tactical component of the experimental group achieved a $8.8 \%$ better performance.

\section{DISCUSSION}

Several authors (Alison, \& Thorpe, 1997; Blomqvist, Luhtanen, \& Laakso, 2001) discovered that by means of a tactical approach, in comparison with the traditional learning, pupils are able to deepen their tactical thinking and ability to make the right decisions during their games. This claim was statistically significant $(p<0.05)$ proved by our research as the evaluation of the tactical component of the games performance "decision-making"). This means that pupils in the experimental group were able to make a better decision about "what" they should do and "how to do it" (to choose a technique). However, they were not better in choosing the right position on the court after hitting the ball although the difference expressed as a percentage is in favour with the experimental group. We think that the pupils in the experimental group were able to make a better decisions based on the variety of modified games they played 2 vs. 2, 3 vs. 3, in which the technical requirements (Light, 2010) are reduced so that all pupils can take part in the game. At the same time the emphasis was placed on the game tactics and the

Popelka, J.\&Pavlović, R.:The effectiveness of various...Sportlogia 2017, 13 (1), 29-37. Page 33. 
development of the physical skills. We agree with (Psotta, 2002) that modified games support pupils' cognitive activity and require the use of appropriate teaching didactic styles. That is why we used in our research different didactic styles in teaching, which overlap the cognitive threshold. For example, after the modified game, there was a discussion where the teacher asked the pupils questions. The pupils tried to find answers to the questions. These didactic styles are regarded as the decisive aspects of education by Webb, Pearson and Forrest (2009). According to Griffin, Mitchell \& Oslin (1997), the performance depends on making tactical decisions, i.e. the ability to identify the problem and find the solution in the given game situation. Based on our observation of evaluation of the level of game performance we can conclude that, in general, experimental group taught through the tactical teaching approach, reached statistically significant $(\mathrm{p}<0.05)$ better quality of game performance than the control groups. In the past Kuchárik (2014) provides similar results in mini handball and Žuffová (2012) in frisbee ultimate. After the evaluation of both groups in individual game activities, the statistically significant $(\mathrm{p}<0.05)$ differences in technique of passing and setting were confirmed in favour of the experimental group. Some authors (Fraňo, 1994; Zapletalová, Čabajová, 2001) state, that the analyticalsynthetic method preferred in technical approach is more effective in learning and improving offensive hit. In our research this claim was not confirmed, because by comparison of offensive hit we found out statistically significant $(\mathrm{p}<0.05)$ the difference between both groups in favour of the experimental group. We think that many modified games allowed the experimental group to get better in offensive hit, because all pupils are often in contact with the ball and can take part in real game situation. Statistically significant difference between both groups was not identified only when serving and therefore we can state the same level of mastering this technique in both groups. These groups have in common that they were the most successful in serving. This can be explained by the fact that serving is a unique activity in volleyball, performed under the standard conditions (Hančík, Mašlejová, \& Tokár, 1994; Zapletalová, \& Přidal, 1996), i.e. serving is not influenced by the quality of the previous gaming activity. We realize that the number of respondents is small and the results can't be generalized. Another research authors (Turner, \& Martinek, 1992; Rink, 1996) compared both approaches in teaching of sports games, did not discover any significant differences of the previously mentioned teaching approaches.

\section{CONCLUSION}

Our results represent only a part of the issue in comparing the effectiveness of various teaching approaches on pupils' game performance in primary schools. From an educational features point of view we used mainly modified games with fewer players ( 2 vs. 2,3 vs. 3$)$ in which we primarily used didactic styles in controlled discovery, didactic style with its individual discovery and didactic style with offer. In our case, the research pointed to this from a complex point of view, the tactical teaching approach appears to be most suitable method of learning game skills and tactical game components. According to the presented results, we can recommend the conclusions for practice:

- use of exercises, based on situational context of the game,

- use of several various didactic styles in one class.

Popelka, J.\&Pavlović, R.:The effectiveness of various...Sportlogia 2017, 13 (1), 29-37. Page 34. 


\section{REFERENCES}

Alison, S., \& Thorpe, R. (1997). A comparison of the effectiveness of two approaches to teaching games within physical education. A skills approach versus a games for understanding approach. The British Journal of Physical Education, 28 (3), 9-13.

Blomqvist, M., Luhtanen, P., \& Laakso, L. (2001). Comparison of Two Types of Instruction in Badminton. In European Journal of Physical Education, 6(2),139-155. https://doi.org/10.1080/1740898010060206

Dobrý, L. (2003). Jak spojit myšlení a pohyb v basketbalovom nácviku. In Tělesná výchova a sport mládeže, 69(4), 25- 30.

PMid: 12689238

Fraňo, J. (1994). K vyučovacím postupom pohybových činností. In Telesná výchova \& Šport, 4(4), 5 - 7.

Griffin, L., L., Mitchel, S., A., \& Oslin, J. (1997). Teaching Sport Concepts and Skills: A Tactical Games Aproach. Retrived from http://classdat.appstate.edu/CHS/HLES/townsnd js/PE\%203009\%20\%20Survey\%20of\%20Sport/Sportfolio/Cricket/Additional\%20Resources/ Assessing $\% 20 \mathrm{O}$ utcomes\%20-\%20GPAI.PDF.

Hančík, V., Mašlejová, D., \& Tokár, J. (1994). Teória a didaktika športovej špecializácie a zvoleného športu volejbal. Bratislava, SL: Univerzita Komenského, Fakulta telesnej výchovy a športu. ISBN 80-223-0584-7.

Kuchárik, I. (2014). Efektivita taktického a technického didaktického prístupu pri výučbe mini-hádzanej 1. až 5. ročníka základných škôl. Bratislava, SL. Diplomová práca. Univerzita Komenského v Bratislave, Fakulta telesnej výchovy a športu, Katedra športových hier.

Lukavská, M. (2006). Výuka volejbalu na středních školách. In Hry 2006: Výzkum a aplikace : sborník referátu ze 7. mezinárodní vedecké konference. Plzeň, $\mathrm{CH}$ : Západočeská univerzita. ISBN 807043-4430, s. 40-44.

Light, R. (2010). Implementing pedagogical innovation in physical education: A case study on the implementation of TGfU pedagogy in a NSW Secondary School. Retrived from $<$ http://www.barker.nsw.edu.au/ subsite.asp?ss=105\&id=4\&pg=9>

Mitchell, S., Oslin, J., \& Griffin, L. (2006). Teaching Sports and Skills: A TActical Games Approach. Second edition. Champaing, IL : Human Kinetics, 560-565. ISBN-13: 9780736054539.

Olosová, G., \& Zapletalová, L. (2014). Effects of a Teaching Games for Understanding Approach and Tactical Approach to Teaching Basketball on Declarative and Procedural Knowledge. In: International scientific conference Sports, Physical Activity and Health. Proceedings. Bratislava: Slovak Scientific Society for Physical Education and Sports, 191-194. ISBN 978-80-89075-44-7.

Popelka, J. (2012a). Porovnanie rôznych prístupov vyučovania na úroveň rozvoja techniky odbitia zdola vo volejbale na II. stupni základnej školy. Exercitatio corporis - motus - salus. 4, (2), 124-130. ISSN 1337-7310.

Popelka, J. (2012b). Vplyv špecifického programu na zmeny úrovne hernej výkonnosti žiakov vo vyučovaní volejbalu na II. stupni základných škôl : dizertačná práca. Banská Bystrica, SL: Fakulta humanitných vied.

Popelka, J. (2013). Comparison of tactical and technical teaching approaches and their influence on the level of volleyball performance of pupils aged 13 and 14. Sport Scientific And Practical Aspects, $10(2), 13-17$

Popelka, J., \& Pavlović, R. (2015). A comparison of different teaching approaches and their impact on the level of theoretical knowledge of volleyball among 13-14 year old pupils. Sport Scientific And Practical Aspects, 12(1), 5-9.

Psotta, R. (2002). Vytváření učebních podmínek pro vyučování sportovním hrám. In Tělesná výchova a sport mládeže, 68(5), $23-29$.

Psotta, R., \& Velenský, M. (2001). Alternativní vyučování sportovních her ve školní tělesné výchově (I). Tělesná výchova a sport mládeže, 67(5), 42-46.

Rink, J. (1996). Tactical and skill approaches to teaching sport and games: Introduction. Journal of Teaching in Physical Education, 15, 397-398. https://doi.org/10.1123/jtpe.15.4.397

Popelka, J.\&Pavlović, R.:The effectiveness of various...Sportlogia 2017, 13 (1), 29-37. Page 35. 
Řezníčková, L., \& Zapletalová, L. (2014). Výučba výberového tematického celku bedminton. In Telesná výchova \& Šport, 24(4), 35- 39. PMCid:PMC4072890

Thorpe, M., Bunker, D., \& Almond, L. (1986). Rethinking Games Teaching. Loughborough: Department of Physical Education and Sport Science, Retrived from $<$ http://www.tgfu.org/articles/PHED\%20 RETHINKING\%20GAMES.pdf $>$

Turner, A., \& Martinek, T. (1992). A comparative analysis of two models for teaching games (technique approach and game centered (tactical focus) approach). International Journal of Physical Education, 24, 131- 152.

Webb, P., Pearson, P., \& Forrest, G. (2009). Expanding the teaching games for understanding (TGfU) concept to include sport education in physical education program (SEPEP). Retrived from $<$ http://ro.uow.edu.au/cgi/viewcontent.cgi?article=1094\&context=edupapers $>$

Zapletalová, L., \& Čabajová, M. (2001). Nácvik a zdokonal'ovanie smeča v školskej telesnej výchove. In Športové hry, 6(2), $31-40$.

Zapletalová, L., \& Přidal, V. (1996). Teória a didaktika volejbalu. Bratislava, SL: Univerzita Komenského, Fakulta telesnej výchovy a športu, 108 s. ISBN 80-967456-1-1.

Zapletalová, L., Přidal, V., Laurenčík, T. (2007). Volejbal. Základy techniky, taktiky a výučby. 1. vyd., Bratislava, SL: Univerzita Komenského, 158 s. ISBN 978-80-223-2280-5.

Zat'ková, V. (2003). Využitie sútaživých foriem pri zdokonal'ovaní prihrávok v extraligovom družstve v hádzanej. Športové hry, 8(1), 8 - 12.

Žuffová, Z. (2012). Efektivita rôznych prístupov k vyučovaniu frisbee ultimate. Bratislava, SL. Diplomová práca. Univerzita Komenského v Bratislave, Fakulta telesnej výchovy a športu, Katedra športových hier.

Žuffová, Z., \& Zapletalová, L. 2015. Efficiency Of Different Teaching Models In Teaching Of Frisbee Ultimate. Acta Facultatis Educationis Physicae Universitatis Comenianae, 55(1), 64-73.

https://doi.org/10.1515/afepuc-2015-0008

Received: 12.04.2017.

Accepted: 23.06.2017.

Correspondence author:

Jaroslav Popelka, PhD.

Katedra telesnej výchovy a športu

Tajovského 40

97404 Banská Bystrica

Slovensko

Tel: 0484467554

Jaroslav.Popelka@umb.sk

Popelka, J.\&Pavlović, R.:The effectiveness of various...Sportlogia 2017, 13 (1), 29-37. Page 36. 


\section{SAŽETAK}

Cilj ovog istraživanja je bio da se odredi i potvrdi efikasnost raznih nastavnih pristupa na promjene u nivou učinka u procesu držanja nastave iz odbojke učenicima $u$ osnovnim školama. U eksperimentalnoj grupi je korišten taktički pristup, a u kontrolnoj grupi tehnički (tradicionalni) pristup u nastavi odbojke. Eksperimentalna grupa se sastojala od 26 učenika a kontrolna grupa od istog broja učenika. Obje grupe su predstavljale djevojčice koje pohađaju osnovnu školu uzrasta, 13-14 godina. Efikasnost nastavnog pristupa je procijenjena na osnovu učinka u igri. Učinak u igri je procijenjen metodom procjene učinka u igri, baziranog na GPAI (instrument za procjenu učinka u igri) kroz video zapise. Mann-Whitney U-test je korišten da se izvrši statistička procjena. Kada se procjenila taktička komponenta učinka igre "pozicija", dolazi se do zaključka da razlika između grupa nije statistički značajna ( $p>0.05)$. Poređenjem komponente "donošenje odluke" otkriveno je da razlika između postignutih učinaka u grupama statistički značajna $(p<0.05)$ u korist eksperimentalne grupe. U poređenju vještina izvršenja saznalo se da razlika između obje grupe u komponenti "serviranje" nije statistički značajna $(p>0.05)$. Ali poređenjem dodavanja, smečovanja, ofanzivnog udarca i učinka u igri tima dobila se statistički značajna $(p<0.05)$ razlika između obje grupe u korist eksperimentalne grupe. Prikupljeni podaci ukazuju na činjenicu da se, u ovom istraživanju, taktički pristup pokazao kao efikasniji metod za sticanje vještina igre i taktičkih komponenti igre.

Ključne riječi: odbojka, nastavni pristupi, učinak

Popelka, J.\&Pavlović, R.:The effectiveness of various...Sportlogia 2017, 13 (1), 29-37. Page 37. 